\title{
Chapter 5 \\ Improving Biodiversity in Rice Paddy \\ Fields to Promote Land Sustainability
}

\author{
Dermiyati and Ainin Niswati
}

\begin{abstract}
Rice is a staple food for many people in the world, especially in Asian countries, and rice consumption increases every year. Efforts have been made to increase rice production, leading to social, economic, and environmental impacts. Rice in paddy fields is mostly grown using conventional farming systems with high inputs of agrochemicals (inorganic fertilizers and chemical pesticides). Continuous application of agrochemicals may damage the soil and cause decreased soil productivity and biodiversity, as well as increased pest attacks and methane emissions. Therefore, organic farming systems are likely to be the best practices for promoting land sustainability. In fact, farmers in many countries have shifted their rice production management from conventional to organic. However, it is argued that, in general, organic systems are related to lower yields and lower environmental impacts while conventional systems are related to higher yields and higher environmental impacts. Although the movement from conventional to organic farming systems is believed to have positive short-term impacts by improving soil biodiversity, therefore, it will also have an impact in terms of lowering rice production volumes. The achievement of food security and food availability requires government policies to promote the use of organic fertilizers and subsidize their prices, as well as regulation to support high prices for organic products. Application of organic fertilizers and biofertilizers, and the use of crop rotation, are likely to improve soil fertility, which is related to increased biodiversity, and eventually this will contribute to higher rice production volumes in the long term.
\end{abstract}

Keywords Biodiversity in rice paddy fields • Conventional and organic farming • Soil biodiversity

Dermiyati $(\square) \cdot$ A. Niswati

Soil Science Department, Faculty of Agriculture, University of Lampung,

Jl. Sumantri Brojonegoro No.1, Bandar Lampung 35145, Indonesia

e-mail: dermiyati@yahoo.co.id; dermiyati.1963@fp.unila.ac.id;

ainin.niswati@fp.unila.ac.id; niswati@yahoo.com 


\subsection{Introduction}

Various types of organisms live in wetland rice and each of them interacts with others to form a specific food chain (Ali 1990; Roger et al. 1993). The direct or indirect effect of one organism on another will affect the community structure of the wetland rice organisms, which consist of nematodes, microcrustacea, protozoa, insect larvae, algae, mollusca, and oligochaetae (Mogi 1993). As the organisms interact with each other, their populations are also affected by environmental factors, including fertilizer and pesticide application, water management, and crop variety (Simpson et al. 1994).

The role and potential of microorganisms and invertebrates in biodiversity and sustainability of wetland rice production has been reviewed by Roger et al. (1991). Suitable rice-producing environments are essential for wetland rice production. It is therefore important to consider microorganisms and invertebrates as well as their biodiversity in wetland rice. Sustainable rice-producing environments depend on microbial and invertebrate populations, agricultural practices, the status of germplasm collection, and developments in biotechnology.

Moreover, whilst crop intensification using agrochemicals does increase yields, on the other hand it also reduces the number of edible species traditionally harvested from ricefields, such as snails, prawns, crabs, large water bugs, fish, and frogs (Heckman 1979). Agrochemicals also cause uncontrolled growth of single species that might, directly or indirectly, have detrimental effects, such as the outbreak of pests (Heinrichs 1988). In addition, fertility- or health-related aspects of ecosystems may be affected by other organisms, such as: (1) blooms of unicellular algae (observed after fertilizer application, which causes nitrogen losses by volatilization); (2) proliferation of ostracods and chironomid larvae (observed after insecticide application, which inhibits the development of efficient nitrogen-fixing blue-green cyanobacterial blooms); and (3) proliferation of snails or mosquito larvae (observed after insecticide application, which causes vector-borne diseases) (Roger and Kurihara 1988).

Nowadays, rice is generally cultivated in two forms: conventional and organic. In Indonesia, however, some farmers choose to follow a middle course, known as "semi-organic." Many reports suggest that organic agriculture is more efficient, and also effective in reducing water and soil pollution (Erhart and Hartl 2009), greenhouse gas emissions (Lumbaraja et al. 1998), and risks to human health (Mader et al. 2002), as well as increasing energy efficiency (Mansoori et al. 2012). Research was conducted in Iran on the relative energy efficiency and economic benefits of organic versus conventional rice production. The organic farms performed better than conventional rice production systems in terms of all energy efficiency indexes, as well as cost-to-benefit ratios and gross and net returns, while total costs of production were also lower (Mansoori et al. 2012). Previously, Lumbaraja et al. (1998) had studied methane emissions from Indonesian rice fields in several locations in Sumatra and Bali. They found that methane emissions in rain-fed conditions were $27-37 \%$ lower than in continuously flooded conditions. In separate research, it was 
noted that paddy fields contribute about $10 \%$ of all global methane emissions (Oyewole 2012).

This chapter considers the sustainability of rice production when shifting from conventional to organic farming systems according to Indonesian experiences. It focuses especially on paddy fields containing microbial and invertebrate populations.

\subsection{Indonesian Experiences: Effects on Soil and Water Biodiversity of Shifting from Conventional to Organic Farming in Paddy Fields}

Most rice field ecosystems in Indonesia are managed using either conventional or organic methods, or a combination of the two. Conventional management involves applying agrochemicals such as inorganic fertilizers and chemical pesticides. Recently, however, the government is socializing organic or semi-organic management methods among farmers' groups. Any resulting change from conventional to organic farming systems is likely to affect biotic environments in rice paddy fields. Although changes in biodiversity are due to the different inputs for conventional farming as opposed to organic, the extent to which inputs affect biodiversity needs to be clarified.

We conducted research during 2006-2007 in the Pagelaran subdistrict of the Tanggamus district in Lampung Province. The research studied how the physical, chemical, and biological properties of soil altered as a result of the farmers changing their rice paddy fields from conventional to organic cultivation. In the following description, however, we will focus only on changes affecting soil and water biodiversity in the paddy fields.

The farmers had cultivated rice in the paddy fields since the 1970s and had used high inputs of agrochemicals, high quality seeds, etc., to generate higher rice production volumes. From the year 2000, however, some farmers who were members of Ikatan Petani Pengendali Hama Terpadu (IPPHT, the Farmers' Association for Integrated Pest Management) realized that although they were using high inputs the rice yields were not increasing anymore and the soil fertility had deteriorated. The soil was hard, and cracking, and lacking in fertility due to reduced levels of organic matter. From then on, therefore, certain farmers pioneered the use of an organic fertilizer called "bokashi." Bokashi was introduced by Japanese farmers; it is a compost made from paddy husk, cow manure, and microorganisms that act as decomposers. Recently it has become very popular in Indonesia too. The farmers make their own bokashi using microorganisms produced using local materials (i.e., papaya fruits are mixed with coconut water and palm sugar, then fermented for 2 weeks, and the supernatant which contains microbes is used as decomposer).

The Pagelaran farmers refer to themselves as organic paddy farmers and they cultivate rice in paddy fields twice a year (there are two seasonal planting periods, 
in the wet and dry seasons). During each planting period they apply about $4 \mathrm{t}$ bokashi ha ${ }^{-1}$ and they do not use chemical fertilizers anymore. They also no longer use chemical pesticides, which they replaced with organic pesticides made from local plants such as tobacco and ginger.

Our study commenced in 2006, and we surveyed farmers who converted to organic methods during the period from 2000 to 2005, since each farmer converted at a different time. Within the sample, therefore, farmers who started organic farming in 2005 had one year's application of bokashi, those who started in 2004 had 2 years of application, and so on. Farmers who had not applied bokashi by 2006 (non-organic farmers) were used as a control (0 years' application). Some farmers did not want to be organic farmers because they were afraid their rice production would be low if they did not use agrochemicals as fertilizers and pesticides. The results of the study are reviewed below.

\subsubsection{Effects on Water Organisms in Paddy Fields}

Aquatic biodiversity in rice fields is endangered as a result of the expansion of human populations. It has led to increasing pressure on living aquatic resources in rice fields due to agrochemical use and runoff, sedimentation, habitat loss, destruction of fish breeding grounds, and unsustainable fishing methods (Halwart 2004).

Information about the types of organism living in paddy fields is necessary because they can serve as indicators for environmental risks. Niswati and Purnomo (2007) studied how the community structure, diversity, and population density of aquatic organisms in Lampung Province was affected by whether paddy fields were conventional or organic (Table 5.1). Their study found 22 types of water organism with a size of $50 \mu \mathrm{m}$ to $1 \mathrm{~cm}$ in the four types of study site. The study sites were categorized according to farming system and location, as follows: (1) Conventional, Taman Bogo; (2) Organic, Pagelaran; (3) Conventional, Pagelaran; and (4) Organic, Greenhouse. Organisms from the groups of Cladocera, Cyclopoida, Ploimida, Zygnemetales, Nematoda, Diptera, Podocopida, Volvocida, and Archipora were found in all locations. However, Anostraca, Ephemeraptera, Closterium, Bdelloida, and Haplatoxida were found only in the conventional paddy fields in Taman Bogo, while a greater total number of organisms was found in Taman Bogo's flooded paddy fields than in Pagelaran. In Pagelaran there were a greater variety of organism types in the organic paddy fields than in the conventional fields. Meanwhile, organism populations in the organic paddy field inside the greenhouse were higher than in the external paddy fields but the organisms were more homogenous.

Organism population changes in the conventional paddy fields in Taman Bogo and Pagelaran, as well as the organic paddy fields in Pagelaran showed that Cladocera, Cyclopoida, Ploimida, and Volvocida are found throughout the duration of plant growth, while other organisms are not. Some organisms, namely Nematodes, Ephemeraptera, and Chlorococcum, are found only at the beginning of plant growth; on the other hand, Bdelloida, Turbellaria, and Archipora are found only at the end 
Table 5.1 Types of water organisms in Lampung Province and their abundances (individual $\mathrm{m}^{-2}$ ) (Niswati and Purnomo 2007)

\begin{tabular}{lrrrr}
\hline & \multicolumn{3}{l}{ Farming system types/locations } & \\
\cline { 2 - 5 } Taxonomic groups & $\begin{array}{l}\text { Conventional, } \\
\text { Taman Bogo }\end{array}$ & $\begin{array}{l}\text { Organic, } \\
\text { Pagelaran }^{\mathrm{b}}\end{array}$ & $\begin{array}{l}\text { Conventional, } \\
\text { Pagelaran }^{\mathrm{b}}\end{array}$ & $\begin{array}{r}\text { Organic, } \\
\text { Greenhouse }^{\mathrm{c}}\end{array}$ \\
\hline Cladocera & 56,608 & 27,520 & 1,152 & 142,500 \\
Cyclopoida & 127,384 & 93,824 & 33,856 & 3,500 \\
Ploimida & 24,192 & 33,600 & 21,88 & 25,250 \\
Zygnemetales & 12,416 & 6,400 & 3,392 & 14,750 \\
Anostraca & 824 & 0 & 0 & 0 \\
Nematoda & 752 & 6,080 & 13,632 & 2,250 \\
Algae spyrogira & 1,288 & 768 & 448 & 0 \\
Diptera & 360 & 1,600 & 1,472 & 4,000 \\
Podocopida & 2,496 & 2,880 & 2,688 & 6,000 \\
Ephemeraptera & 280 & 0 & 0 & 0 \\
Closterium & 688 & 0 & 0 & 0 \\
Bugs & 1,064 & 64 & 0 & 0 \\
Isopoda & 584 & 0 & 192 & 0 \\
Chlorococcum & 1,240 & 0 & 0 & 11,500 \\
Volvocida & 5,280 & 640 & 1,344 & 19,500 \\
Bdelloida & 200 & 0 & 0 & 0 \\
Haplatoxida & 216 & 0 & 0 & 0 \\
Turbellaria & 480 & 3,328 & 1,088 & 10,750 \\
Paramecium & 0 & 128 & 576 & 40,750 \\
Euglenida & 0 & 256 & 1,408 & 82,500 \\
Archipora & 1,158 & 1,280 & 0 & 0 \\
Sessilida & 0 & 192 & 128 & 0 \\
\hline Sera & & & & 0
\end{tabular}

${ }^{a}$ Seven observations

${ }^{\mathrm{b}}$ Five observations

${ }^{\mathrm{c}}$ Ten observations

of plant growth. Meanwhile, Podocopida, Algae Spyrogira, Zygnemetales, Diptera, Closterium, Bugs, and Haplatoxida were found inconsistently. This type of succession was similar to that reported by Yamazaki et al. (2004).

In comparison, surveys conducted in Sri Lanka on biodiversity in wetland rice field ecosystems documented 494 species of invertebrates belonging to 10 phyla, and 103 species of vertebrates, while the flora included 89 species of macrophytes, 39 genera of microphytes, and 3 species of macrofungi (Bambaradeniya et al. 2004).

Moreover, changes affecting dominant protozoa and algae populations in conventional and organic paddy field flooding water in Lampung Province were also studied (Niswati et al. 2008). There were two genera of protozoa (Euglena sp. and Pleodorina sp.) and two genera of algae (Volvox sp. and Diatom) that were dominant in the paddy fields where bokashi was continuously applied (Fig. 5.1). Among dominant protozoa, the population of Volvox sp. was significantly influenced by the continuous application of bokashi. The populations of protozoa and algae were higher under continuous bokashi application (for 2-4 years) than under the control. 

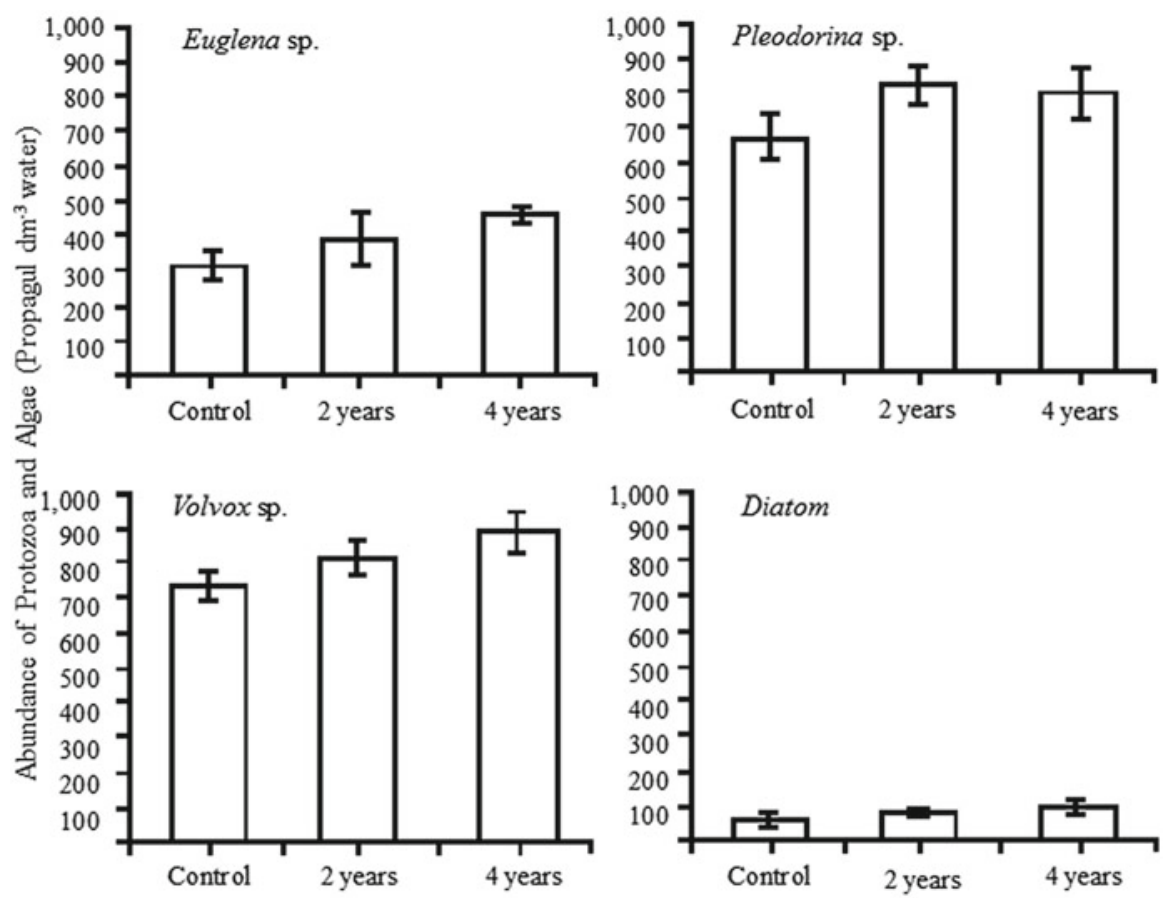

Duration of Bokashi Application

Fig. 5.1 Abundance of dominant protozoa and algae in paddy field water where bokashi was applied continuously. Bars indicate standard error $(\mathrm{P}=0.95)$ (Niswati et al. 2008)

Fluctuation in numbers of protozoa and total algae in organic paddy fields was higher than under conventional cultivation systems, the highest being after 4 years of bokashi application. Meanwhile, other protozoa and algae were also found, namely Chlorococcum, Archipora, Bdelloida, Algae Spyrogira, and Ploimida, but they were not dominant.

Populations of dominant protozoa and algae were likely to increase, starting 30 days after planting and continuing steadily until harvesting time (data not shown). This is because continuous application of bokashi compost may increase the populations of bacteria and fungi in the soil (Labidi et al. 2007) as well as increasing carbon biomass, nitrogen, phosphorus, and sulfur. Bacteria and fungi can act as food sources for protozoa, so continuous application of bokashi may increase microbial activity in the soil, which may increase the protozoa population. The decreases in protozoa and algae populations that occurred at 30 and 60 days after planting time were due to organic paddy field management involving weed cutting, wetting by irrigation, and drying out of the water in the paddy fields.

The biodiversity index for protozoa and algae was the same for both conventional and organic paddy fields. It is likely that the application of bokashi compost 
affected all organisms in the flooding water of the paddy fields so that the food chain was not yet affected.

In separate research, Roger et al. (1991) summarized some studies from multiple countries about species abundance in traditional rice fields. They reported that based on a 1975 study in Thailand the species abundance in one traditional rice field in 1 year was 590 species (excluding fungi) (Heckman 1979). Moreover, about 39 taxa of aquatic invertebrates were reported following a 2-year study of pesticide application on Malaysian rice fields (Lim 1980). Across 18 sites in the Philippines and India the highest number of aquatic invertebrate taxa reported was 26 and the lowest was 2 by single sampling at individual sites (Roger et al. 1987). Based on these data recorded from 1975 to the present, they stated that crop intensification had a tendency to decrease the values for total number of species; however, it cannot be accepted as a general concept that crop intensification decreases biodiversity in rice fields (Simpson et al. 1994).

\subsubsection{Effects on Soil Microorganisms in Paddy Fields}

The soil microbial community is involved in numerous ecosystem functions, such as nutrient cycling and organic matter decomposition, and plays a crucial role in the terrestrial carbon cycle (Schimel 1995). Changes in populations of phosphate solubilizing microorganisms in conventional and organic paddy fields were also studied (Dermiyati et al. 2009). Although the populations of phosphate solubilizing microorganisms were not affected by continuous application of bokashi and the contribution to soil $\mathrm{P}$ from bokashi was relatively low, the microorganisms did play a role in the availability of soil available-P from residual $\mathrm{P}$ fertilizers that were applied intensively for long periods. Figure 5.2 shows the changes in phosphate solubilizing microorganism populations as a result of converting from conventional to organic paddy fields by applying bokashi continuously.

Roger et al. (1991) also reviewed effects of crop intensification on soil and water microbial populations. The impacts of crop intensification on the rice field microflora due to pesticide use are: (1) alteration of activities related to soil fertility, and (2) reduction of pesticide efficiency because of shifts in microbial populations toward organisms more efficient in their degradation.

\subsection{Strategies to Improve Biodiversity in Rice Paddy Fields}

There are measures that can be taken to improve biodiversity in rice paddy fields, such as continuous application of organic fertilizers. Alternatively, biofertilizers can be applied to introduce microorganisms that benefit nutrient cycles and energy supply. Farmers can also undertake crop rotation to cut the life cycles of pests. 


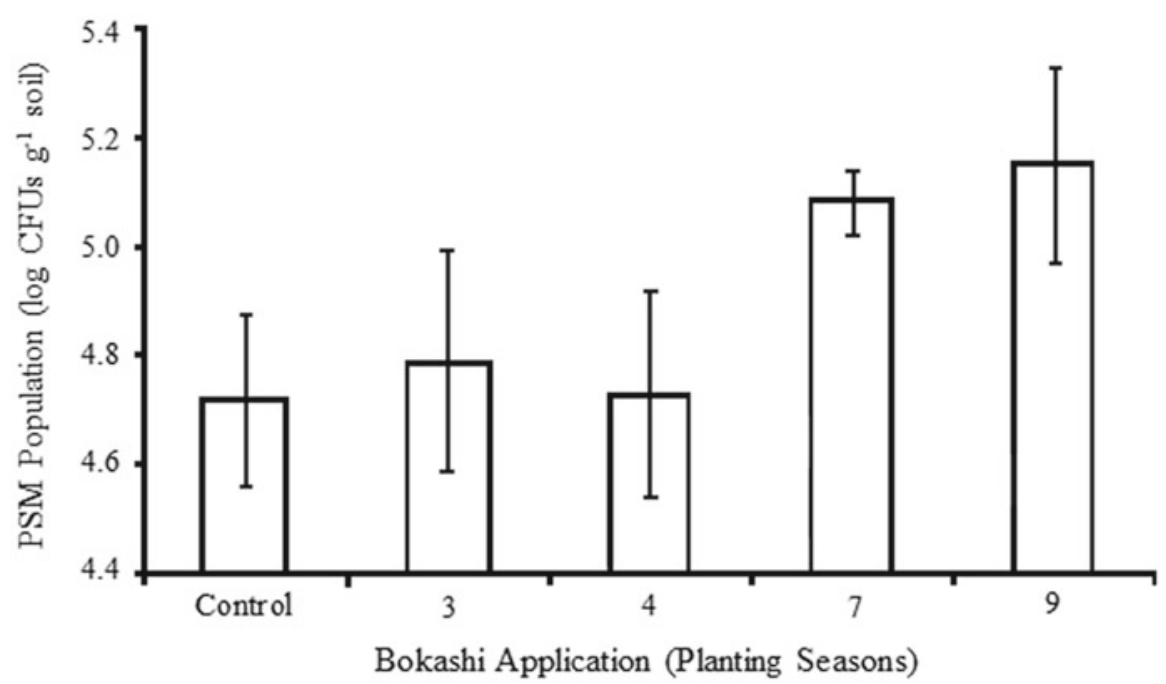

Fig. 5.2 Populations of phosphate solubilizing microorganisms (PSM) as a result of conversion from conventional to organic paddy fields by applying bokashi continuously in the Pagelaran subdistrict. Bars indicate standard error $(\mathrm{P}=0.95)$ (Dermiyati et al. 2008)

\subsubsection{Application of Organic Matter and Biofertilizers}

In theory, addition of organic matter promotes biological and microbial activities that accelerate the breakdown of organic substances in the organic matter. The use of organic materials such as animal manure, crop residues, green manure, and bokashi compost as alternative sources is promising.

Soil microbial biomass comprises living plant roots and organisms, and the living portion of soil organic matter. It acts as the agent of biochemical changes in soil and as a repository of plant nutrients such as nitrogen $(\mathrm{N})$ and $\mathrm{P}$ in agricultural ecosystems (Jenkinson and Ladd 1981). Lower microbial biomass in soils from conventional agro-ecosystems is often caused by reduced organic carbon content in the soil (Fliebach and Mader 2000). The quantity and quality of organic inputs are the most important factors affecting microbial biomass and community structure (Peacock et al. 2001). Continuous cultivation with frequent tillage results in rapid loss of organic matter through increased microbial activity (Shepherd et al. 2001).

Nakhro and Dkhar (2010) observed that the application of organic fertilizers increased fungal and bacterial populations as well as microbial biomass carbon compared to the application of inorganic fertilizers or a control. The increases were found both at surface soil depth $(0-15 \mathrm{~cm})$ and at sub-surface soil depth $(15-30 \mathrm{~cm})$; however, the increases were greater at sub-surface soil depth. This could be due to the addition of organic amendments that might have a large impact on soil microbial activity (Elliot and Lynch 1994), microbial diversity (Girvan et al. 2004), and bacteria density (Bruggen-van and Semenov 2000). 


\subsubsection{Crop Rotation}

The main components of organic farming systems are soil protection, bio-control, nutrient cycles, and biodiversity. So far, farmers' efforts have been limited to replacing the use of agrochemicals (fertilizers and pesticides) with organic fertilizers (such as compost) and pesticides. However, this approach primarily addresses soil protection, and only partly influences bio-control and nutrient cycles, while no attention has yet been focused on biodiversity. Although monoculture is part of the "Green Revolution," or conventional, farming systems, it still prevails in paddy fields that have been declared organic. In order to improve biodiversity, therefore, crop rotation is necessary in these paddy fields.

Crop rotation affects microbial populations. Research in the Pagelaran district showed that there were differences in the populations of phosphate solubilizing microbes in paddy fields where bokashi compost was continuously applied. Crop rotation from paddy to legumes caused a decrease in the population of phosphate solubilizing microbes (Dermiyati et al. 2009). It was likely that the cultivation of legumes increased the nitrogen-fixing bacteria rhizobium. These bacteria have an ability to fix nitrogen from the air and make it available for the plant by cooperation with legume roots. Moreover, it was observed that the activity of phosphate solubilizing bacteria in the rhizosphere was affected by the presence of nitrogen- fixing bacteria like rhizobium (Widawati 1999).

\subsection{Conclusions}

As mentioned previously, improvements are necessary in rice paddy fields where heavy chemicals have been applied so that biodiversity can be maintained and sustainability in wetland rice growing is achieved. Shifting from conventional to organic farming needs a strong policy from the government to make organic fertilizers available at prices farmers can afford, or to subsidize their prices for the farmers. Government policy has to encourage and incentivize farmers who conduct organic farming and support high prices for organic products. Meanwhile, the farmers themselves must change their habits and culture with regard to paddy field cultivation to increase yields for food security. In relation to food security, production of organic fertilizers that contain high levels of nutrients is recommended. In addition, agricultural extension must teach the farmers simple technologies such as how to make bokashi or compost using local materials available in the villages.

To establish organic agriculture as an important tool in sustainable food production, assessments of the many social, environmental, and economic benefits of organic farming systems need to be complemented by a fuller understanding of the factors limiting organic yields. Agro-ecologists and conservation biologists should work together to formulate strategies based on biodiversity as an organizing principle in the sustainable management of rice field agro-ecosystems. 
Open Access This article is distributed under the terms of the Creative Commons Attribution Noncommercial License which permits any noncommercial use, distribution, and reproduction in any medium, provided the original author(s) and source are credited.

\section{References}

Ali AB (1990) Seasonal dynamics of microcrustacean and rotifer communities in Malaysian rice fields used for rice-fish farming. Hydrobiologia 206:139-148

Bambaradeniya CNB, Edirisinghe JP, De Silva DN, Gunatilleke CVS, Ranawana KB, Wijekoon S (2004) Biodiversity associated with an irrigated rice agro-ecosystem in Sri Lanka. Biodivers Conserv 13(9): 1715-1753

Bruggen-van AHC, Semenov AM (2000) In search of biological indicators for soil health and disease suppression. Appl Soil Ecol 15:13-24

Dermiyati AJ, Yusnaini S, Nugroho SG (2009) Change of phosphate solubilizing bacteria population on paddy field with intensive farming became sustainable organic farming system. J Trop Soils 14(2):143-148 (in Indonesian)

Elliot LF, Lynch JM (1994) Biodiversity and soil resilience. In: Greenland DJ, Szabolcs I (eds) Soil resilience and sustainable land use. CAB International, Wallingford, pp 353-364

Erhart E, Hartl W (2009) Soil protection through organic farming: a review. In: Lichtfouse E (ed) Organic farming, pest control and remediation of soil pollutants. Sustain Agric Rev 1: 203-226

Fliebach A, Mader P (2000) Microbial biomass and size-density fractions differ between soils of organic and conventional agricultural systems. Soil Biol Biochem 32:757-768

Girvan MS, Bullimore J, Ball AS, Pretty JN, Osborn AM (2004) Response of active bacterial and fungal communities in soil under winter wheat to different fertilizer and pesticide regimens. Appl Environ Microbiol 70:2692-2710

Halwart M (2004) Aquatic biodiversity in ricefields. International year of rice: rice is Life. www.rice2004.org

Heckman CW (1979) Ricefield Ecology in Northeastern Thailand. (Monographiae Biologicae). Dr. W. Junk bv Publishers, Hague, p 228

Heinrichs EA (1988) Role of insect-resistant varieties in rice IPM systems. In: Teny PS, Heong KL (eds) Pesticide management and integrated pest management in Southeast Asia. International Crop Protection, Bettsville

Jenkinson DS, Ladd JN (1981) Microbial biomass in soil: measurement and turnover. In: Paul EA, Ladd JN (eds) Soil biochemistry. Marcel Dekker, New York, pp 415-471

Labidi S, Nasr H, Zouaghi M, Wallander H (2007) Effects of compost addition on extra-radical growth of arbuscular mycorrhizal fungi in Acacia tortilis sp. raddiana savanna in a pre-Saharan area. Appl Soil Ecol 35:184-192

Lim RP (1980) Population changes of some aquatic invertebrates in ricefields. In: Tropical ecology and development. Proceedings of the 5th international symposium of tropical ecology. International Society of Tropical Ecology, Kuala Lumpur, pp 971-980

Lumbaraja J, Nugroho SG, Niswati A, Ardjasa WS, Subadiyasa N, Arya N, Haraguchi H, Kimura M (1998) Methane emission from Indonesian ricefields with special references to the effect of yearly and seasonal variations, rice variety, soil type and water management. Hydrolog Process 12:2057-2072

Mader O, Flie-Bach A, Gunst L, Fried P, Niggli U (2002) Soil fertility and biodiversity in organic farming. Science 296:1694-1697

Mansoori H, Moghaddam PR, Mohadi R (2012) Energy budget and economic analysis in conventional and organic rice production systems and organic scenarios in the transition period in Iran. Front Energ 6(4):341-350. doi:10.1007/s11708-012-0206-x 
Mogi M (1993) Effect of intermittent irrigation on mosquitoes (Diptera: Culicidae) and larvivorous predators in rice fields. J Med Entomol 30:309-319

Nakhro N, Dkhar MS (2010) Impact of organic and inorganic fertilizers on microbial populations and biomass carbon in paddy field soil. J Agron 9(3):102-110

Niswati A, Purnomo (2007) The changes of communities and diversity of aquatic organisms on the floodwater of paddy fields of Pagelaran and Taman Bogo, Lampung Province. J Akta Agrosia (Special Edition) 2:213-219 (in Indonesian)

Niswati A, Dermiyati, Arif MAS (2008) Changes in the dominant population of protozoa and algae inhabiting the floodwater of paddy fields subjected to continued bokashi application. J Trop Soils 13(3):225-231 (in Indonesian)

Oyewole OA (2012) Microbial communities and their activities in paddy fields: a review. J Vet Adv 2(2):74-80

Peacock AD, Mullen MD, Ringelberg DB, Tyler DD, Hedrick DB, Gale PM, White DC (2001) Soil microbial community responses to dairy manure or ammonium nitrate applications. Soil Biol Biochem 33:1011-1019

Roger PA, Kurihara Y (1988) Floodwater biology of tropical wetland rice fields. In: Proceedings of the first international symposium on paddy soil fertility, University of Chiang Mai, Thailand, 6-13 December 1988, pp 275-300

Roger PA, Santiago-Ardales S, Watanabe I (1987) The abundance of heterocystous blue-green algae in rice soils and inocula used for application in rice fields. Biol Fertil Soils 5:96-105

Roger PA, Heong KL, Teng PS (1991) Biodiversity and sustainability of wetland rice production: role and potential of microorganisms and invertebrates. In: Hawksworth DL (ed) The biodiversity of microorganisms and invertebrates: its role in sustainable agriculture, CAB International, Wallingford, England, pp 117-136

Roger PA, Zimmerman WJ, Lumpkin TA (1993) Microbial management of wetland rice fields. In: Metting FB Jr (ed) Soil microbial ecology: applications in agricultural and environmental management. Marcel Dekker, Inc., New York, pp 417-455

Schimel DS (1995) Terrestrial ecosystem and carbon cycle. Global Change Biol 1:77-91

Shepherd TG, Sagar S, Newman RH, Ross CW, Dando JL (2001) Tillage-induced changes in soil structure and soil organic matter fractions. Aust J Soil Res 39:465-489

Simpson IC, Roger PA, Oficial R, Grant IF (1994) Effects of nitrogen fertilizer and pesticide management of floodwater ecology in a wetland rice field II. Dynamics of microcrustaceans and dipteran larvae. Biol Fertil Soils 17:138-146

Widawati S (1999) Effect of soil microbe application on the growth and yields of soybean (Glycine $\max$ L.) in an acid soil. J Microbiol Trop II(2):61-67 (in Indonesian)

Yamazaki M, Hamada Y, Kamimoto M, Momii T, Kimura M (2004) Composition and structure of aquatic organism communities in various water conditions of a paddy field. Ecol Res 19:645-653 